\title{
NEUROSIENCE DAN PENGALAMAN KEAGAMAAN ( SPRITUAL) KASUS KORUPSI
}

\author{
Hammi Latifah \\ Konsentrasi Bimbingan dan Konseling Islam \\ Pascasarjana Universitas Islam Negeri Sunan Kalijaga Yogyakarta \\ (E-mail: hammilatifah521@gmail.com)
}

\begin{abstract}
Corruption experienced the dynamics of its mode, run systematically, synergistically, calmly and "solemnly". The age around forty years down marks some young, wealthy people, with a pragmatic lifestyle and hedonist. They are the middle class with the predicate scholarship a number of public and private universities. As explained in neurosciences that the soul as well as spirituality is the product of the human brain although the mechanisms for bringing the two are different. It is interesting to understand the necessity of recruiting candidates for the professional leaders of this state organization by finding out what is the relationship between a healthy brain, a close connection to the meaning of life and spirituality. The theory of neurosciences is highly recommended, at least learn from interpreting the perpetrators of corruption including the class of learned, a method of recruitment of public leaders capable of producing human elected. And neuroscience can be a government policy to involve a spiritual neuroscience approach in doing the fit and proper test of a country's stakeholder candidate. So that eventually hopefully through neuroscience and ISHA can contribute to the form of recruitment methods that can capture healthy and sane leaders of the brain, the fruit of the presence of God in the human brain.

Keywords: neuroscience, spiritual, corruption, ISHA.
\end{abstract}

\begin{abstract}
Abstrak
Korupsi mengalami dinamika modusnya, dijalankan dengan sistematik, sinergis, tenang, dan "khusyuk".Usia diseputar empat-puluh tahun ke bawah menandai sejumlah orang muda, kaya-raya, dengan gaya hidup pragmatis dan hedonis. Mereka merupakan kelas menengah dengan predikat kesarjanaan sejumlah perguruan tinggi negeri dan swasta. Sebagaimana dijelaskan dalam neurosains bahwa jiwa maupun spritualitas adalah produk otak manusia meskipun mekanisme untuk memunculkan keduanya berbeda. Neurosains bisa menjadi kebijakan pemerintah untuk melibatkan pendekatan neurosains spritual dalam melakukan fit and proper test calon pemangku amanah negara. Sehingga nanti akhirnya diharapkan melalui neurosains dan ISHA mampu memberikan konstribusi berupa metode rekrutmen yang mampu menjaring pemimpin yang sehat dan waras otaknya, buah dari hadirnya Tuhan dalam otak manusia.

Kata kunci: Neurosains, Spritual, Korupsi, ISHA.
\end{abstract}




\section{A. Latar belakang}

Dalam realitanya, kenikmatan sesaat semu dan bersifat tipuan belaka ini (korupsi) menandai sebagian kelompok hedonis termasuk yang sedang diuji dengan kekuasaanya. Kekuasaan yang sejatinya menjadi sarana dan wahana luar biasa mulianya dengan ketinggian dan keunggulan marwahnya di hadapan rakyat dan Tuhan. Bohong kepura-puraan, tampil sok bersahabat, ramah, dan keluwesan melakukan apa saja inilah sifat kesehariannya. Tak jelas bahkan teramat sulit untuk menemukan ciri pembeda antara lisan jujur dan dusta mereka. Dunia materi, keindahan dan kemewahan semu yang menandai aktivitas harian mereka. Dalam mind set nya terpola “apa lagi yang harus dijarah".Mereka merupakan kelas menengah dengan predikat keserjanaan sejumlah perguruan tinggi negeri dan swasta.

Sebagai kelas terpelajar seharusnya mampu melakukan aktivitas yang, mencerminkan profesionalisme, pencerdasan, serta pembebasan rakyat yang sejumlah 40 jutaan masih bertengger dalam garis kemiskinan absolut. Jika dibandingkan dengan abad jahiliyah di jazirah arab masalampau, yang ditandai dengan simbol keterpanggilan kepada rakyat kelas budak yang tertindas oleh sistem sosial politik tak bermartabat kala itu. Dalam suasana serba jahiliyh di jazirah arab, usia 40 tahun ditandai dengan hadirnya tangan Allah untuk mengangkat hambanya dengan di wisudanya Muhammad bin Abdullah sebagai Nabi.

Mengapa di negeri kaya raya yang kandungan mineral berjuta pada zaman modern ini ditandai dengan hadirnya Generasi Muda Koruptor (GMK)? Apa dan siapa yang salah dengan hadirnya koruptor muda ini, di tengah sebagian besar anak-anak muda yang masih terawat, kepribadiannya. Korupsi kendatipun mencapai derajat "budaya bangsa" tetapi musuh bersama (common enemy) ini telah menghasilkan pemiskinan massif terhadap rakyat sebagai pemangku paling dominan negeri beragama ini. Korupsi dalam bentuknya berupa penjarahan harta negara yang menjadi hak rakyat maupun dalam bentuk lainnya berupa abuse of power juga telah meluluhlantahkan bangunan akhlak dan spritualitas masyarakat.

Derita rakyat karena korupsi tidak terbatas pada aspek keuangan negara tetapi sekaligus pemiskinan moralitas bangsa. Periaku korupsi dan kandidatya 
yang terbentuk dalam proses kaderisasi koruptor seperti menderita "kelainan jiwa" yang kronis. Hal ini tampak dalam laku mereka yang fasih dan refleks dalam berbohong. Tak jarang ditemukan daya tahan dan konsistensi keberbohongan mereka pada tingkat yang di tangguh di depan publik maupun aparat penyidik. Bagi yang belum terbiasa menghadapinya, sangat mungkin tidak percaya jika Tuhan pun dibawa-bawa dan dijadikan "bumper" untuk meyakinkan publik dan penegak hukum bahwa dirinya "tidak bersalah". Berani sumpah, sumpah pocong dan siap menerima lakhnat Tuhan, adalah ciri kefasihan para koruptor itu. Untunglah Tuhan tidak menyandang "sifat ketersinggungan".

Sifat ini justru melekat pada mereka yang peka dan antikritik. Dalam kasus ini, atau untuk memandang dari sudut pandang ilmiah mengnai perilaku menyimpang, merebaknya korupsi, relasi antara manusia dan kelompok yang tercerabut dari kesadaran nilai-nilai fitrahnya dengan segala dampak distruktifmulti dimensionalnya akibat dusta struktural dan pemisifitas di kalangan masyarakat, kita memerlukan upaya membangun intelektualisme religius. yakni, pengambaraan akal fikiran yang tidak di belenggu doktrin lapuk " scince for science" dan "value free" yang telah berhasil membunuh peradaban autentik kemanusiaan. Kita memerlukan pendidikan yang menurut Comte sebagaimana yang dikatakan K.J. Vegeer bukan pendidikan yang intelektualistik melulu dan bertujuan menambah pengetahuan semata, tanpa motivasi dan cinta kasih, yang akan menghasilan intelektualisme kering dan nasionalisme tandus.

Akal budi manusia tidak memiliki tempat tinggi, tetapi hati yang terluhur. Pengundulan nilai-nilai budaya bangsa berbasis agama dan keanekaragaman multikulturalisme semakin mengganas akaibat korupsi sebagai buah sifat dusta. Sejak dari parasnya terguras tanda dusta. Korupsi adalah pembunuhan massif secara pelan dan sangat menyakitkan yang tergolong pada "crime againt humanity". Pada dasarnya Al-Quran sangat menjungjung tinggi keadilan sebagaimana Karen Amstrong sampaikan: "pesan Al-quran cukup sederhana: tidak dibenarkan menumpuk kekayaan untuk kesenagan pribadi, tetapi dianggap kebaikan jika memberikan derma serta membagi kekayaan secara merata". Seharusnya tidak ada kata terlambat untuk menghadirkan jalan keluar atas 
kemelut dan gambaran kondisi darurat bangsa yang tengah dilanda demoralisasi merata ini.

Sejalan dengan Comte diatas, akal budi sangat memerlukan dukungan aktif jiwa yang bersih, sebagaimana Murthada Muthahari mengatakan, "jika manusia melakukan penyucian jiwa, maka pandangan rasionya akan menjadi terang". Upaya menyelamatkan bangsa adalah gerakan memperbaiki akhlak. Bukan merebut perhatian rakyat dengan model hegemoni politik dan retorika kosong. Ketika elite birokrasi lebih banyak beretorika, maka rakyat akan semakin malas menaggapinya.

\section{B. Landasan Teoritis}

1. Neurosains

Neurosains merupakan bidang ilmu yang secara khusus mempelajari tentang sel-sel saraf atau neuron. ${ }^{1}$ Wattimena $\mathrm{R}$, dalam Memperkenalkan status Neurosains menyatakan Ilmu ini mempelajari segala sesuatu tentang otak manusia, mengkaji unsur-usur biologisnya, serta mempelajari proses hubungan manusia dengan Tuhan. ${ }^{2}$ Neurosains merupakan gabungan banyak sekali bidang keahlian, ilmuan, dan objek penelitian yang berkaitan dengan otak. Saat ini pendekatan neurosains telah menyentuh dimensi spritual, yang lebih di kenal dengan istilah neurosains spritual. Istilah ini dipakai untuk menjelaskan spritualitas manusia di pandang dari sisi persfektif kedokteran. Spritualitas merupakan keyakinan yang berkaitan dengan yang Maha Kuasa dan Maha Pencipta. Spritualitas merupakan bagian penting dari kesehatan karena di duga dapat berperan sebagai penyembuh dari segala macam penyakit.

2. Otak Normal dan Otak Sehat: dasar-dasar neurosains bagi kesehatan spritual

Istilah otak normal dan otak sehat sudah sering dipakai dengan makna yang hampir sama dan tumpang tindih. Dalam situs brain foundation misalanya otak sehat (healthy barain) dipakai dalam kaitan dengan penuaan otak. Taufiq Pasiak mislanya membuat sebuah skema mengenai otak sehat dan normal.

\footnotetext{
${ }^{1}$ Taufiq Pasiak,dkk,"Hubungan Kinerja Otak Dengan Spritualitas Manusia Diukur Dengan Menggunakan Indonesia Spritual Health Asesment Pada Pemimpin agama di Kota Tomohon ," Jurnal e-Biomedik (Ebm), Volume 1, Nomor 2, (Juli 2013), h. 831.

${ }^{2}$ Taufiq Pasiak,dkk,"Hubungan Kinerja Otak..., h. 831.
} 


$$
\mathrm{O}_{2}=\mathrm{O}_{1}(\mathrm{~K}+\mathrm{S})
$$

KET $: \mathrm{O}_{2}=$ Otak Sehat

$$
\mathrm{O}_{1}=\text { Otak Normal }
$$

$\mathrm{K}=$ Keterampilan Berfikir

$\mathrm{S}=$ Spritualitas

Kaitan antara kesehatan spritual dengan otak sehat berdasarkan skema diatas memiliki dua alasan diantaranya :

a. Tubuh juga berperan penting dalam kesehatan spritual. Tubuh diperankan oleh otak biologis.

b. Dengan membicarakan otak dengan kesehatan spritual, maka terbuka kemungkinan penyatuan neurologi ( ilmu saraf) dan psikiatri ( ilmu jiwa); dua bidang yang semula bersatu kemudian berpisah.

Jadi dapat disimpulakan bahwasanya otak normal (normal brain) lebih umum dikaitkan dengan usia dan fase perkembangan otak yang dicitrakan atau digambarkan oleh sejumlah alat periksa otak, terutama yang memeriksa anatominya. Dengan demikian otak abnormal ialah otak yang anatominya tidak sesuai dengan keadaan perkembangannya yang sejalan dengan usia.

Berdasarkan definisi ini, maka anak-anak yang menyandang autisme, misalnya merujuk pada teori biologis yang mendasarinya memiliki perkembangan otak yag tidak normal. Penyakit jiwa skizofrenia misalnya, ialah ketidak normalan bagian tertentu otak yang sebenarnya sudah mulai terjadi ketika otak berkembang. Pendapat ini hendak menyatakan bahwa penyakit skizofernia itu lebih condong ke "bakat" biologis otak ketimbang gangguan mental atau pascatrauma. ${ }^{3}$ Dengan demikian, sskizofrenia sesungguhnya sebuah bentuk otak tidak normal ( abnormal brain ) yang dengan alat-alat canggih bisa diketahui abnormalitas tersebut.

Otak sehat dikaitkan dengan keterampilan berfikir (skill of thinking). Karena keunggulan manusia terletak pada kemampuannya berfikir. ${ }^{4}$ Kemampuan berfikir tidak berarti rasionalisme yang memutlakkan rasio atau rasionalitas atau berfikir logis yang semata-mata berdasarkan hal empirik; yang semata-mata

${ }^{3}$ Daniel R, Weinberger, M.D, "Implication Of Normal Brain Development for the Pathogenesis of Schizophrenia", Arch Gen Psychiatry, 1987; 44 (7), h. 660.

${ }^{4}$ Taufiq Pasiak, Revolusi IQ/EQ/SQ: Antara Neurosains dan Alqur'an, (Bandung: Penerbit Mizan, 2002), $h$. 
mengandalkan rasio dan logika dalam mengambil keputusan, merencanakan masa depan atau membuat nilai-nilai (values) kehidupan. Keterampilan dirujuk secara neurobiologis sebagai koordinasi dinamis-hubungan sirkuit neural-antara Cortex prefrontalis $(\mathrm{CPF})$ dan sistem limbik (terutama amygdala). ${ }^{5} \mathrm{CPF}$ adalah bagian Otak yang memiliki sirkuit paling banyak dan paling lengkap ke dan seluruh bagian otak lain. Dinamika neural di CPF sangat aktif karena terlibat dalam setiap kegiatan di wilayah otak lain.

Faktanya, dalam kehidupan sehari-hari kegiatan berfikir manusia terjadi sebagi hubungan dinamis antara CPF dan sistem limbik (terutama amygdala). Jika CPF mengontrol Amygdala maka lahirlah kemampuan berfikir manusia dalam pengambilan keputusan ( decision making). Misalnya jika kita melihat gagasan dari Kahneman yang menjelaskan secara praktis, apa dan bagaimana otak sehat itu karena kekuatan utama manusia, terletak pada kemampuannya dalam hal membuat keputusan atau kemampuan eksekusi. CPF sering disebut sebagai kemampuan eksekusi manusia dan menjadi bagian penting dari "kepribadian". Fungsi eksekutif meliputi antara lain: atensi, memori, working memory, perencanaan, integrasi temporal, pembuatan keputusan, monitoring dan kontrol penghambatan. ${ }^{6}$ Melihat sejumlah komponen eksekutif yang vital dan utama dalam kehidupan manusia, maka fungsi eksekutif yang dijalankan secara spesifik oleh CPF sangatlah penting.

3. Pengalaman beragama (spritual)

Pengalaman spritual merupakan salah satu komponen dari spritualitas dan basis utama dar spritualitas. Normal states of counsciousness merupakan pengalaman penyatuan dengan alam semesta yang tidak dapat di peroleh pada kesadaran biasa. Merujuk pada kondisi beberapa pengalaman yang membawa seseorang pada keadaan menyatu dengan sesuatu yang diyakininya sebagai yang suci. Pengalaman spritual merupakan suatu keadaan "mengalami” dari spritualitas yang dijelaskan diatas. Semua orang memiliki spritualitas, tetapi tidak semuanya “mengalami” spritualitas tersebut. Merujuk pada Newberg, secara neurobiologis,

\footnotetext{
${ }^{5}$ Istialah "sistem limbik" disebut kali pertama oleh ahli anatomo prancis Piere Paul Broca tahun 1878 dengan sebutan/e grande lo be limbique.

${ }^{6}$ Joaquin M. Fuster, The Prefontal Cortex, Edisi ke-4 (New York: Elsevier, 2008), h. $178-192$
} 
pengalaman mistis berbentuk suatu continuum, yang terdiri dari pengalaman estetis pada bagian paling bawah, lalu berturut-turut menjadi ketakjuban (awe), cinta dan penyatuan (union mystica, aninhilasi, atau fana'). ${ }^{7}$

Spritualitas adalah potensi bawaan manusia yang membuatnya terhubung dengan kekuatan yang lebih besar, sehingga dia merasa ada keterkaitan antara dirinya dan alam semesta, yang secara aplikatif di tunjukkan dalam sejumlah nilai. Spritualitas bersifat universal, bersifat transetnik, taransgeografis, transpolitik, transekonomi, dan tidak ada pembatas antara satu mausia dan manusia lain. Karena itu jika seseorang memiliki nilai-nilai spritualitas ini, maka ia tidak melihat orang lain dalam ruangan yang terbatas, misalnya perbedaan agama formal atau perbedaan suku dan bangsa.

Mengutip pendapat Danah Zohar, spritualitas yang diambil dari kata latin "sprit" (sesuatu yang memberikan kehidupan atau vitalitas pada sebuah sistem) merujuk pada semacam kebutuhan manusia untuk menempatkan upaya dirinya dalam satu kerangka makna dan tujuan yang jelas. Spritualitas inilah yang membuat manusia selalu bertanya mengapa seseorang melakukan apa yang dia lakukan dan membuat manusia mencari cara-cara bertindak yang secara fundamental lebih baik. Unsur-unsur inilah yang membuat seseorang berupaya untuk menciptakan perubahan dunia. ${ }^{8}$

Spritual dibedakan dengan agama, dimana agama berarti menganut satu agama dan juga berarti kita masuk dalam satu komunitas. Oleh sebab itu, agama atau beragama membuat manusia itu berbeda dengan manusia lainnya dalam hal status, sedangkan spritual lebih bersifat individualistik, yang terfokus pada bagaimana seseorang melaksanakan hal-hal yang dianggapnya benar dan yang dipercayai. ${ }^{9}$

4. Persfektif neurosains tentang spritualitas.

Neurosains spritual merupakan bidang neurosains yang mengkhususkan diri pada penelitian pada aspek-aspek neurobilogis dari pengalaman spritual.

\footnotetext{
${ }^{7}$ A.B Newberg, Eugene D'Aquili. Why God Won't Go Away: Brain science and the Biology of Belief (New York: Balantine Books. 2001), h. 22-23.

${ }^{8}$ Danah Zohar, Spritual Capital: Memberdayakan SQ di Dunia Bisnis (Bandung: Mizan, 2005), h. 63.

${ }^{9}$ TaufiqPasiak, Tuhan dalam Otak Manusia (Bandung: Mizan, 2012).
} 
William james dapat dikaitkan sebagai pemula dibidang ini ketika dia menyinggung di dalam bukunya hubungan neurologi dan agama. Kajian james berfokus pada psikologi, kajian yang bersifat makro karena melihat hubungan yang kuat antara psikolgi dan biologi (neurologi). Meskipun lebih banyak aspek psikologis, terutama mempelajari sentimen-sentimen agama (religius sentimen) dan dorongan-dorongan agama (religius impulse) secara spekulatif james sudah menyinggung tentang faktor-faktor biologis, terutama otak dalam melahirkan spritualitas tersebut.

Sejalan dengan canggihnya alat penelitian, neurosains spritual dikembangkan secara cepat dan memfokuskan perhatiannya pada kinerja otak hidup dan memasuki wilayah molekuler. Penelitian dengan menggunakan alat seperti PET dan SPECT mampu melihat area- area otak yang terlibat dalam kegiatan spritual. Objek penelitian pun tidak terbatas pada orang-orang biasa, tetapi juga pada ruhaniawan yang melakoni meditasi atau yoga, atau sejenisnya. Pada level molekuler para ahli berhasil mengetahui neurotransmiter yang berperan dalam hal-hal yang berkaitan spritualitas.

\section{Kasus korupsi}

Istilah korupsi berasal dari bahasa latin, yakni corruption atau corruptus yang disalin dalam bahasa Inggris menjadi corruption atau corrupt, dalam bahasa Perancis menjadi corruption dan dalam bahasa Belanda disalin menjadi corruptie (korruptie). Asumsi kuat menyatakan bahwa dari bahasa Belanda inilah kata itu turun ke bahasa Indonesia, yaitu Korupsi. Arti harfiah dari kata korupsi ialah kebusukan, keburukan, kebejatan, ketidakjujuran, dapat disuap, tidak bermoral, penyimpangan dari kesucian, kata-kata atau ucapan yang menghina atau memfitnah. $^{10}$

Kamus Besar Bahasa Indonesia memuat pengertian korupsi sebagai "penyelewengan atau penggelapan (uang negara atau perusahaaan, dan sebagainya untuk keuntungan pribadi atau orang lain). ${ }^{11}$ Dari uraian pengertian sederhana diatas, dapat dipahami bahwa arti dan kandungan makna korupsi sangat luas,

${ }^{10}$ M. Nurul Irfan, Korupsi Dalam Hukum Pidana Islam, (Jakarta : Amzah, 2014),

${ }^{11}$ Departemen Pendidikan dan Kebudayaan, Kamus Besar Bahasa Indonesia, (Jakarta: Balai Pustaka), h. 527. 
tergantung dari bidang dan perspektif pendekatan yang dilakukan. Dari semua arti secara etimologis maupun terminologis, korupsi mempunyai arti yang semuanya mengarah kepada keburukan, ketidakbaikan, kecurangan bahkan kezaliman, yang akibatnya akan merusak dan menghancurkan tata kehidupan keluarga, masyarakat, bangsa, dan negara.

\section{Penyebab korupsi}

Berbagai perspektif dari para ahli dalam menentukan faktor penyebab kasus ini, seperti yang dijelaskan oleh Baharuddin Lopa dalam bukunya M. Nurul Irfan bahwa penyebab terjadinya korupsi di Indonesia awalnya disebabkan karena kondisi sosial ekonomi yang rawan sehingga orang melakukan korupsi dengan motif mempertahankan hidupnya. Akan tetapi, kian lama motif ini bergeser menjadi motif ingin memperoleh kemewahan hidup. Penyebab lainnya adalah berupa kelemahan mekanisme organisasi dan tidak dilaksanakannya fungsi pengawasan secara wajar. Hal ini akan mendorong seseorang yang tidak kuat imannya melakukan korupsi. ${ }^{12}$

Zohar dan Marshaall menjelaskan adanya keterkaitan pemahaman spiritual terhadap kebahagiaan dan kebermaknaan hidup. Ketika seseorang menyadari arti dan makna seorang pemimpin untuk apa ia dipercayai oleh rakyat, ia akan jauh dari sikap-sikap dan tindakan yang buruk. Kecerdasan spiritual akan membantu seseorang dalam menyembuhkan dan membangun diri secara utuh. Walau pun itu tidak harus diperoleh dari agama, dengan kata lain sekalipun ia seorang ateis. Akan tetapi disinipenulislebihcenderungkepadapendapat Zohar dan Marshall tentang signifikansi kecerdasan spiritual (SQ) terhadap kebermaknaan hidup, yang menurut hemat penulis masih banyak parapejabat pemerintahan krisis nilai dan makna sehingga masih mementingkan dirinya dari pada warga negaranya. Dengan demikian, penulis mengambil kesimpulan bahwa faktor penyebab korupsi secara umum dapat diklasifikasikan menjadi dua macam, yaitu faktor internal dan faktor eksternal. Faktor internal berkaitan dengan pelaku korupsi itu sendiri sebagai pemegang amanat berupa jabatan dan wewenang yang diembannya. Sedangkan faktor eksternal berupa sistem pemerintahan dan kepemimpinan serta pengawasan yang tidak seimbang sehingga bisa membuka peluang terjadinya korupsi.

\footnotetext{
${ }^{12}$ M. Nurul Irfan, Korupsi Dalam Hukum Pidana Islam, h. 36.
} 
Rekapitulasi penyidikan tindak pidana korups

Yang Ditangani Oleh KPK RI

\begin{tabular}{|c|c|c|c|c|c|c|c|c|c|c|c|}
\hline Jabatan & 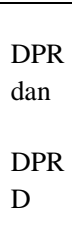 & $\begin{array}{l}\text { Kemen } \\
\text { trian }\end{array}$ & $\begin{array}{l}\text { Duta } \\
\text { Besar }\end{array}$ & $\begin{array}{l}\text { komi } \\
\text { sione } \\
\mathrm{r}\end{array}$ & $\begin{array}{l}\text { Gube } \\
\text { rnur }\end{array}$ & $\begin{array}{l}\text { Waliko } \\
\text { ta/ } \\
\text { Bupati }\end{array}$ & $\begin{array}{l}\text { Eso } \\
\text { len } \\
\text { I,II, } \\
\text { III }\end{array}$ & $\begin{array}{l}\text { Haki } \\
\text { m }\end{array}$ & Swasta & lain & $\mathrm{Jlh}$ \\
\hline 2004 & & & & & 1 & & 2 & & 1 & & 4 \\
\hline 2005 & & 1 & & 3 & & & 9 & & 4 & 6 & 23 \\
\hline 2006 & & 1 & & 2 & 2 & 3 & 15 & & 5 & 1 & 29 \\
\hline 2007 & 2 & & 2 & 1 & & 7 & 10 & & 3 & 2 & 27 \\
\hline 2008 & 7 & 1 & 1 & 1 & 2 & 5 & 22 & & 12 & 4 & 55 \\
\hline 2009 & 8 & 1 & & & 2 & 5 & 14 & & 11 & 4 & 45 \\
\hline 2010 & 27 & 2 & 1 & & 1 & 4 & 12 & 1 & 8 & 9 & 65 \\
\hline 2011 & 2 & & & & & 5 & 7 & 3 & 11 & 5 & 33 \\
\hline 2012 & & & & & & 2 & & & & 1 & 3 \\
\hline Jumlah & 46 & 6 & 4 & 7 & 8 & 29 & 91 & 4 & 55 & 30 & 284 \\
\hline
\end{tabular}

Sekedar memberikan sedikit gambaran tentang peta korupsi untuk membaca bagaimana kelakukan kumuh ini dilakukan bukan oleh kelas tidak terpelajar, melainkan justru kelas menengah terpelajar. Data dibawah ini menunjukkan tidak adanya kolerasi tingkat pendidikan formal dan kelas menengah lain dengan perilaku korupsi yang mereka lakukan.

Data diatas menggentakkan nurani dan nalar sehat kita bahwa pendidikan yang tidak berbasis pada keterpaduan dan itegrasi antara dimensi ruh ke ilahi-an (transendental), dengan sistem kerja dan aktivitas otak manusia, hanya akan melahirkan sarajana tukang yang sebagiannya berpotensi sebagai "pelacur dan koruptor intelektual".

7. Neurosains sebagai landasan Konseling spritual dalam penyelesaian kasus korupsi

Hingga saat ini, neurosains telah berkembang menjadi disiplin ilmu dengan cakupan luas, terbentang dari pembahasan tentang hal-hal yang besifat biologis hingaga psikologis dan filsafat, bahkan teologis. Luasnya dimensi 
ontologis dan aksiologis dari neurosains membuka peluang baginya untuk menjadi semacam aditeori terpadu (Grand unified theory) yang dapat menjelaskan banyak aspek dari manusia. Aditeori terpadu ini merujuk kepada sejenis ilmu yang dicita-citakan oleh fisikawan, untuk menjelaskan alam semesta secara menyeluruh. Stephen Hawking fisikawan dari Oxford adalah orang terdepan yang mecita-citakan Aditeori terpadu ini. Menurutnya ilmu ini harus bisa menggabungkan relativitas umum (yang menjelaskan hukum-hukum yang mengatur alam besar pada tingkat bintang-bintang) dan asas ketidak pastian (yang bekerja pada pada partikel-partikel kecil).

Sekalipun disadari masih ada banyak keterbatasan, tetapi neurosains memiliki peluang yang sangat besar untuk menjadi sebuah sains yang menerangkan manusia dari perspektif otaknya. Berbagai data dari kasus-kasus klinik, kerusakan otak dan penggunaan obat-obatan, kajian fisiologis hubungan jiwa badan (mind body relation) dan berbagai kajian otak pada level molekular membantu para ahli untuk memahami bagaimana dinamika manusia secara utuh. Kemajuan ini menghasilkan konsep-konsep baru sekitar makna person dan personality, dan bagaimana mereka berinteraksi untuk menghasilkan manusia yang memiliki kesadaran. ${ }^{13}$ Jika diasumsikan bahwa kesadaran (conciousness) dan "manusia sadar" (human being) sebagai bagian terpenting dari setiap sains tentang manusia, maka neurosains dalam banyak hal telah melakukan telaah dan menghasilkan hasil-hasil yang sangat menantang tentang hal ini. Riset-riset tentang berbagai komponen yang membentuk kesadaran, mulai level molekuler hingga level sosial, menjadi topik-topik utama dalam neurosains:

a. Seluler-Molekuler

Mengkaji berbagai macam sel saraf dan bagaimana mereka melakukan fungsi-fungsi spesifik yang berbeda satu dengan yang lain untuk menghasilkan berbagai perilaku yang kompleks seperti emosi, kognisi, dan tindakan. Proses belajar misalnya dilihat dari dalam proses interaksi berbagai molekul kimia di sinaps.

${ }^{13}$ Arbib Michael, "Toward Neurocienceof The Parson". Dalam Russel, Murphy, Meyering, Arbib (eds.), Neuroscience and the Parson: Scientific Perspective on Divine Action. (Vatican Observatory and Center for the Theology and the Natural Science, 1999), h. 77-79. 
b. Sistem

Mengkaji sel-sel saraf yang berfungsi sama dalam sebuah sistem yang kompleks. Mislanya masalah pengelihatan di kaji dalam "sistem visual" masalah gerakan tubuh dikaji dalam "sistem motorik" masalah pendengaran di kaji dalam sistem "auditorik" dan lain-lain.

c. Neurosains Perilaku

Mengkaji bagaimana beberapa sistem itu bekerja sama untuk menghasilakan perilaku tertentu. Misalnya, bagaiamana sistem-sistem yang berbeda menghasilakn bentuk-bentuk memori yang berbeda; bagian mana dari otak yang berurusan dengan "kognisi”. "emosi”, bahasa dan lain-lain.

d. Neurosains Sosial

Merupakan kandidat kuat dalam aplikasi Neurosains dibidang sosial. Bidang ini mempelajari bagaimana "otak sosial" manusia berperan dalam membantu manusia membentuk hubungan dengan orang lain. Kemampuan manusia untuk menjalin hubungan dengan orang-lain merupakan naturenya yang tersimapan secara biologis dalam otak. Sekalipun bukan termasuk sistem yang terlokalisasi dan mudah diidentifikasi dengan jelas, "otak sosial" memiliki akar yang kuat dalam interaksi antara berbagai bagian. Komponen lobus frontal, seperti: cortex prefrontal, cortex orbitofrontal, dan cortex ventromedial merupakan komponen utama yang bertanggung jawab untuk itu. Dengan demikian, interaksi antar manusia tidak saja dikaji oleh ilmu-ilmu sosial, antropologi, ekonomi, dan politik, tetapi juga dapat dikaji dengan neurosains. Ini beralasan karena, sebagaimana dinyatakan dalam paradigma baru ilmu fisika terdapat asas kesaling tergantungan (interdependency) antara berbagai bagian di alam semesta, tak terkecuali otak manusia.

Tidak heran, kasus kerusakan otak depan yang parah seperti terjadi pada penderita stroke, tumor otak, infeksi-infeksi atau degenerasi, dapat mengubah kepribadian. Penderita skizofrenia atau sindroma autis, yang sekarang semakin diyakini merupakan kelainan otak dapat merubah kepribadian. Pada penderita sindroma autis, yang di cirikhasi oleh gangguan komunikasi, dan emosi lebih banyak memiliki akar biologis daripada psikologis atau sosiologis. Kerusakan pada amygdala, nucleus nervus facialis, dan berbagai komponen otak depan dan 
batang otak kerap ditemukan pada penderita autis yang diotopsi. Tidak saja kasus klinis, Paul Mclean telah menemukan akar-akar biologis yang menjadi sebab seseorang menjadi kriminalis yaitu kerusakan pada sistem limbik, yang menurut Paul merupakan sistem yang masih bisa ditemukan pada hampir semua binatang.

Otak memiliki kemampuan berubah yang disebut neuroplastisitas. Otak dapat berubah strukturnya oleh karena berbagai faktor yang datang dari lingkungan. Otak laksana mesin hidup yang dapat berubah sepanjang waktu,otak kita hampir selalu merupakan barang baru. Kebaruannya karena sel-sel otak berubah setip saat melalui pembentukan sinaps. Keunikan lain otak adalah kemampuannya untuk melakukan judgement terhadap sesuatu. Jika kita melihat perempuan cantik dan kemudian melakukan hubungan seks, padahal dia bukan merupakan istri yang sah, maka berbagai komponen otak segera bekerja secara sinergis untuk memberikan umpan balik bahwa ini merupakan tindakan yang keliru. Melalui kerja manoamin yang bernama serotonindan dopamin. Pengalaman perseptif kita dikaitkan dengan nilai dan emosi.

8. Implementasi neurosains dalam konteks konseling lintas budaya dan agama

a. Pengertian konseling spiritual

Konseling spritual adalah konseling yang mengarahkan konseli kepada Tuhan dengan asumsi dasar bahwa manusia adalah makhluk yang beragama dan ciptaan Tuhan. Konseling sendiri berasal dari bahasa latin consilium yang memiliki arti "dengan" atau "bersama" atau dapat diartikan "menerima" atau "memahami”. Sehingga konseling dapat diartikan sebagai proses pemberian bantuan yang dilakukan oleh seorang tenaga ahli (profesioanal/konselor) kepada yang membutuhkan (klien) dalam menyelesaikan masalah yang dihadapinya dan bermuara atas teratasinya masalah yang dihadapi oleh klien tersebut. ${ }^{14}$

b. Prinsip-prinsip dalam konseling spritualitas

1) Selalu memiliki prinsip landasan dan prinsip dasar yaitu beriman kepada Tuhan.

2) prinsip kepercayaan, yaitu beriman kepada Malaikat Memiliki prinsip kepemimpinan, yaitu beriman kepada nabi dan rasulnya.

${ }^{14}$ Prayitno, dan Erman Amti; Dasar-Dasar Bimbingan dan Konseling, (PT Rineka Cipta; Jakarta, 2004), h. 99 
3) Selalu memiliki prinsip pembelajaran, yaitu berprinsip kepada Al-Quran alKarim.

c. Unsur-unsur konseling Spritual

Konselor

a) pembimbing harus mempunyai pengetahuan yang cukup luas, baik dari segi teori maupun dari segi praktik.

b) Bisa mengambil tindakan yang bijaksana

c) harus sehat dari segi jasmani maupun rohaninya.

d) harus mempunyai inisiatif yang cukup baik.

e) bersifat supel, ramah tamah, sopan santun di dalam segala perbuatannya. Konseli

a) Motivasi berupa kesediaan untuk membicarakan masalah itu dengan penyuluhan, dan ada keinginan untuk mencari penyelesaian dari maslah itu.

b) Keberanian untuk mengekspresiakan diri.

c) Keinsyafan akan tanggung jawab yang dipikul sendiri akan keharusan berusaha sendiri.

d. Dimensi-dimensi agama dalam proses konseling.

Pendapat Glock (1962) juga dapat menjadi perspektif lain untuk melihat bagaimana agama/spritualitas berhubungan dengan kesehatan. Menurutnya setiap agama memiliki Lima dimensi yang saling berkaitan dengan menerangkan apa sesungguhnya yang terjadi dalam proses keberagamaan. ${ }^{15}$

1) Dimensi Ideologis

Merupakan dimensi keimanan seseorang, cara dia memandang realitas berdasarkan dogma atau iman yang dipercayainya. Dalam kaitan dengan penyakit, dimensi ideologis memengaruhi cara seseorang memandang penyakit, termasuk bagaimana Tuhan terlibat dalam proses penyakit dan kesembuhannya.

2) Dimensi Intelektual

pengetahuan agama mencakup tentang pengetahuan kitab suci atau sumber informasi lain,simbol-simbol dan cerita, yang biasanya terpadu dalam suatu teologi. Meski tidak semua penganut agama/spritualitas memiliki pengetahuan

\footnotetext{
${ }^{15}$ Glock C.Y, "On The Study of religious commitment", Religious Educaw.
} 
yang cukup tentang kepercayaan yang dianutnya, tetapi bagi orang-orang tertentu agama merupakan hal penting. Konselor tidak mesti memahami secara mendalam dimensi intelektual agama, tetapi pengetahuan secukupnya merupakan hal penting yang dapat membantu dalam proses konseling.

3) Dimensi Ritual

Kehadiran di tempat ibadah,berdo'a, partisipasi dalam upacara agama, mendengar nyanyian atau musik religius dapat merupakan sumber kenyamanan bagi orang-orang tertentu, dan dapat membantu penderita untuk melakukan coing terhadap stres karena penyakit serius atau karena masuk rumah sakit misalnya.

4) Dimensi Eksperiensial

Dimensi ini berkaitan dengan pengalaman religius yang dialamai dan mempengaruhi kehidupan. Pengalama religius dapat berupa pengalaman biasa maupun pengalaman spektakuler dimana seseorang mengalami atau merasakan kehadiran figur tertentu yag diyakininya sebagai Tuhan. Menurut fetzer berdasarkan riset nya dimensi spritual merupakan pengalaman spritual harian. Yang nantinya melalui pemahaman dimensi keberagamaan ini, kita jadi lebih mudah dalam melakukan bimbingan dan konseling kepada konseli melalui bimbingan spritual dengan lintas agama dan budaya.

C. Pembahasan

a. Pengertian ISHA (Indonesia Spritual Health Assesment)

Indonesia Spritual Health Assesment (ISHA) atau assesment dan fit and proper test .Indonesia menggunakan alat ukur yang disebut Indonesia Spritual Health Assesment (ISHA) yang merupakan uji yang dibuat oleh tim Centre For Neuroscience, Health and Sprituallity (CNET). Uji ini berbasis Neurosains, dan juga memuat tentang profil spritual manusia sehingga kita dapat mengetahui kecenderungan manusia berlaku sesuai dengan nilai-nilai agama.

ISHA (Indonesia Spritual Health Assesment) berbentuk kuesioner yang dibuat berdasarkan konsep-konsep teoritis spritualitas, yang terdiri dari 3 komponen 16

1) Spritual health item

${ }^{16}$ Taufiq Pasiaq, Asesment Spritualitas Otak, Launcing CNET, Disampaikan di Aula UIN Sunan Kalijaga, Yogyakarta 26 Januari 2012. 
Terdiri dari 90 item soal untuk memerikasa 24 indikator kesehatan spritual. Pertanyaannya dalam bentuk simulasi imajinatif.

2) Brain system assesment

Terdiri dari 27 soal untuk mengecek sistem otak yang dominan bekerja.

3) Neurofeedback

Alat pemeriksaan yang berfungsi supporting terhadap ISHA. Tidak berhubungan langsung dengan konsep spritualitas di atas, tetapi memberikan dukungan berarti berkaitan dengan kondisi terperiksa. Kegiatan spritual dalam otak manusia merupakan hasil kerja dari sejumlah komponen otak yang dinamakan "operator kognitif" komponen spritual ini bekerja untuk menghasilakan pengalaman spritual. Operator kognitif terdiri dari: korteks prefrontalis, Area Asosiasi, Sistem Limbik, dan sistem saraf otonom.

4) Assesment dan fit and proper test ( sejarah pengukuran spritualitas)

Pengukuran spritualits memiliki sejarah yang panjang, meskipun hingga saat ini banyak para ahli yang mengakui bahwa instrument-instrument itu belum sepenuhnya bisa memetakan agama dan spritualitas manusia, apalagi jika sudah dikaitkan dengan kesehatan. Francis Galton dapat diakatakan sebagai orang pertama yang mencoba meneliti secara statistik dan sistematik beberapa hal yang berkaitan dengan agama. Gakton merancang sebuah kuisioner dan membuat rating scale dalam psikologi agama. Pada tahun 1872 jauh sebelum Harbert Benson dan Harold Koening melakukan penelitian tentang do'a dan kesehatan, Galton sudah meriset tentang efektivitas do'a dan pengaruhnya dalam kehidupan si pendeta. ${ }^{17}$

Alat alat ukur yang sudah pernah dibuat dapat dikelompokkan kedalam 4 kelompok berikut ini. Ada yang memang diarahkan secar langsung mengukur spritualitas dan agama, ada juga yang merupakan salah satu bagian saja dari alat ukur yang ditujukan untuk hal lain:

5) Mengukur kualitas hidup, antara lain misalnya McGill Quality of Life Questionnaire, ada 3 dari 20 item dengan spritualitas, Mc Master Health Index Questionnaire, 3 dari 24 pertanyaan relevan dengan spritualitas; The Hospice Index, 4 dari 34 relevan dengan spritualitas.

${ }^{17}$ David M. Wulff, "Psikology of religion: classic and the contemporary", (New York: John Wiley and Sons Inc, 1997), h. 205-206. 
6) Mengukur perilaku, antara lain Death Attitude Profile, 21 item, Purpose In life Test, 28 item; The Seeking of NeoticGoals Test, 20 Item; Life Attitude Profile, 36 item.

7) Mengukur religiositas, antara lain Religious Coping Scale, 50 item religious;ReligiousOrientation Measure, 20 item;The Religiousness Scale, 12 item.

8) Mengukur Spritualitas antara lain spritual well being scale, 20 item; Meaning In Life Scale, 15 item; Herth Hope Index, 12 Item.

Lahirnya sejumlah pemeriksaan ini bukannya tanpa masalah. Persoalan Validitas ('apakah ukuran itu mengukur yang hendak diukur") dan reliabilitas (“apakah hasilnya akan sama jika diukur dengan orang yang sama, tapi waktu yang berbeda") juga menjadi masalah utama. Validitas alat ukur sangat ditentukan oleh definisi operasional yang dibuat. Spritualitas yang diartika sebagai perasaan bermakna (meaning life), akan berbeda alat ukur yang valid dengan spritualitas yang diartikan sebagai perasaan menyatu (oneness). Reliabilitas juga bukannya tanpa masalah. Pengalaman spritual (spritual experience) pasti reliabilitasnya akan rendah karena pengalaman ini akan berbeda-beda, bervariasi naik turun, pada orang yang sama dan pada waktu yang berbeda. Persis seperti pernyataan seorang kiai yang ada di Indonesia "iman itu naik turun, kadang diatas, kadang dibawah". Selain validitas dan reliabilitas, sensitivitas juga menjadi hal penting.sensitivitas akan memberikan seberapa banyak dimensi spriyualitas maupun agama yang dapat dilingkupi oleh sebuah tes.

2. Peran konselor dalam kasus korupsi

Jika diperhatikan kasus "korupsi (Assesment dan fit and proper test)" ini lebih kepada Ruang Lingkup Neurosains Sosial karena adanya sistem yang buruk. Dan jika dikaitkan dengan peran konseling, dalam kasus ini hal yang biasa dan dapat dilakukan oleh seorang konselor ialah : melakukan proses pendekatan konseling kepada instansi atau birokrasi terutama KPK (Komisi Pemberantasan Korupsi) yang menangani hal ini. Tentunya dengan menggunakan konseling spritual berlandaskan teori neurosains. Artinya kita bisa menawarkan kepada intansi atau birokrasi yang menaungi bahwa konsep neurosains bisa dijadiakan salah satu asesment dalam rekrutmen aparatur negara. 
Neurosience dan Pengalaman Keagamaan... (Hammi Latifah) 343

\section{Kesimpulan}

Pencegahan korupsi diperlukan upaya intelektualisme yang lebih inovatif, melalui observasi, dengan daya nalar tinggi untuk menemukan fakta-fakta dan menganalisisnya serta untuk meramalkan kejadian-kejadian yang akan datang sebagaimana dikatakan A Syafii Maarif dengan mengutip Bertrand Russel. Tujuannya adalah membangun teori baru menyelamatkan bangsa yang sebagian besar rakyatnya masih terawat hati, akal sehat, dan spritualitasnya. 


\section{Daftar Pustaka}

Pasiak Taufiq, dkk. "Hubungan Kinerja Otak Dengan Spritualitas Manusia Diukur Dengan Menggunakan Indonesia Spritual Health Asesment Pada Pemimpin agama di Kota Tomohon."Jurnal e-Biomedik (Ebm). Volume 1, Nomor 2. Juli 2013.

R Daniel, Weinberger, M.D. "Implication Of Normal Brain Development for the Pathogenesis of Schizophrenia." Arch Gen Psychiatry. 1987.

Pasiak Taufiq. Revolusi IQ/EQ/SQ: Antara Neurosains dan Alqur'an, Bandung:

Mizan, 2002.

Fuster M. Joaquin. “The Prefontal Cortex.” Edisi ke-4 New York: Elsevier. 2008. Newberg A.B, D'Aquili Eugene. "Why God Won't Go Away: Brain science and the Biology of Belief." New York: Balantine Books. 2001.

Zohar Danah. Spritual Capital: Memberdayakan SQ di Dunia Bisnis. Bandung: Mizan, 2005.

Pasiak Taufiq. Tuhan dalam Otak Manusia. Bandung: Mizan,2012.

Nurul Irfan M, Korupsi Dalam Hukum Pidana Islam. Jakarta: Amzah, 2014.

Kamus Besar Bahasa Indonesia. Departemen Pendidikan dan Kebudayaan. Jakarta: Balai Pustaka.

Michael Arbib. "Toward Neurocienceof The Parson". Dalam Russel, Murphy, Meyering, Arbib (eds.), Neuroscience and the Parson: Scientific Perspective on Divine Action. Vatican Observatory and Center for the Theology and the Natural Science. 1999.

Prayitno, M.Sc.Ed. dan Amti Erman. Dasar-Dasar Bimbingan Dan Konseling Jakarta: PT Rineka Cipta, 2004.

C.Y, Glock. "On The Study of religious commitment." Religious Educaw.

Pasiak Taufiq. "Asesment Spritualitas Otak." Launcing CNET, Disampaikan di Aula UIN Sunan Kalijaga, Yogyakarta 26 Januari 2012.

M. Wulff David. "Psikology of Religion: Classic and The Contemporary." New York: John Wiley and Sons Inc, 1997. 